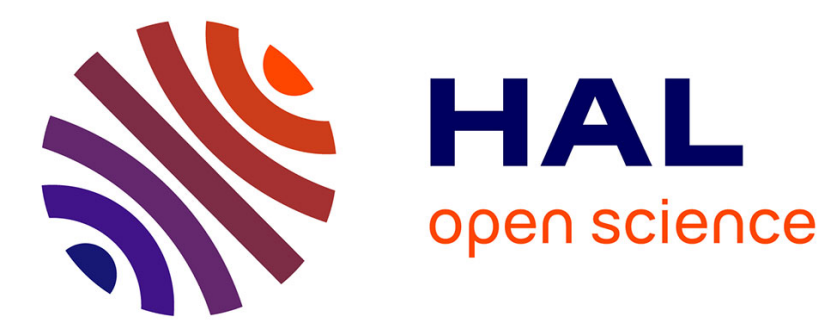

\title{
Novel insights into the genetic diversity of Parafavella based on mitochondrial CO1 sequences
}

Jae-Ho Jung, Ji Hye Moon, Kyung-Min Park, Sanghee Kim, John Dolan, Eun Jin Yang

\section{- To cite this version:}

Jae-Ho Jung, Ji Hye Moon, Kyung-Min Park, Sanghee Kim, John Dolan, et al.. Novel insights into the genetic diversity of Parafavella based on mitochondrial CO1 sequences. Zoologica Scripta, 2018, 47 (6), pp.743-755. 10.1111/zsc.12312 . hal-02337262

\section{HAL Id: hal-02337262 \\ https://hal.sorbonne-universite.fr/hal-02337262}

Submitted on 29 Oct 2019

HAL is a multi-disciplinary open access archive for the deposit and dissemination of scientific research documents, whether they are published or not. The documents may come from teaching and research institutions in France or abroad, or from public or private research centers.
L'archive ouverte pluridisciplinaire HAL, est destinée au dépôt et à la diffusion de documents scientifiques de niveau recherche, publiés ou non, émanant des établissements d'enseignement et de recherche français ou étrangers, des laboratoires publics ou privés. 
Zoologica Scripta

DOI: $10.1111 /$ zsc. 12312

Novel insights into the genetic diversity of Parafavella (Ciliophora, Spirotrichea) based on nuclear ribosomal genes and mitochondrial $\mathrm{CO} 1$ sequences

Jae-Ho Jung ${ }^{1,}$, Ji Hye Moon ${ }^{1}$, Kyung-Min Park ${ }^{2}$, Sanghee Kim ${ }^{2}$, John R. Dolan ${ }^{3}$, Eun Jin Yang 4

${ }^{1}$ Department of Biology, Gangneung-Wonju National University, Gangneung, South Korea

${ }^{2}$ Division of Life Sciences, Korea Polar Research Institute, Incheon, South Korea

${ }^{3}$ Sorbonne Universite's, UPMC Univ Paris 06, CNRS UMR 7093, Laboratoire d'Oce' anographie de Villefranche-sur-Mer, Station Zoologique, 06230 Villefranchesur-Mer, France

${ }^{4}$ Department of Polar Ocean Environment, Korea Polar Research Institute, Incheon, South Korea

*Correspondence: Jae-Ho Jung, Department of Biology, Gangneung-Wonju National University, 7 Jukheon-gil, Gangneung, South Korea, 25457. T: 8233640 2312, Email jhjung@gwnu.ac.kr 


\begin{abstract}
We used both nuclear ribosomal genes (28S rDNA, 18S rDNA, 5.8S rDNA, internal transcribed spacer regions: ITS1, ITS2) and mitochondrial CO1 sequences to group or distinguish morphotypes of Parafavella, a problematic genus of tintinnid ciliates of the marine microzooplankton. We sequenced 30 single cells of Parafavella from the Bering Sea, the Greenland Sea, and the East/Japan Sea. Sequences were obtained from 4 morphotypes, typically ascribed to $P$. gigantea, $P$. greenlandica, $P$. jorgenseni, and $P$. subrotundata and from GenBank, the nuclear ribosomal genes of $P$. parumdentata were retrieved. Cells of the 5 morphotypes had identical $18 \mathrm{~S}$ and $5.8 \mathrm{~S}$ gene sequences. ITS1, ITS2 and 28S sequences produced two clusters: one grouping $P$. greenlandica and $P$. parumdentata and the other grouping $P$. jorgenseni, $P$. gigantea, and $P$. subrotundata. In contrast, $\mathrm{CO} 1$ nucleotide data yielded eight haplotypes clustered into five groups: one composed of $P$. greenlandica morphotypes, two distinct haplotypes of $P$. jorgenseni, and two distinct haplotypes of $P$. gigantea with one including $P$. subrotundata morphotypes. We investigated the co-occurrence of different morphotypes in samples from sites across a large gradient of latitude and concentrations of Parafavella cells. Natural communities contained 2-6 different morphotypes. We conclude that both the crypticity within morphotypes and species polymorphism characterize Parafavella, as known for other tintinnid genera.

Keywords: cryptic species, marine plankton, polymorphism, Tintinnidea,
\end{abstract}




\section{INTRODUCTION}

There is a great deal of interest in assessing boreal flora and fauna given the rapid changes that have already occurred and are anticipated to continue in high latitude ecosystems. In a recent report on arctic marine biodiversity, the chapter on plankton (Lovejoy et al., 2017) specifically points out the scarcity and need for species data on phytoplankton and heterotrophic protists of the microzooplankton. Here we report on some tintinnid species of the microzooplankton commonly found in waters of the Arctic Ocean as well as the North Pacific and North Atlantic Oceans, forms that have long considered being 'troublesome'. These are forms of the genus Parafavella. The trouble investigators have had is distinguishing morphotypes described as distinct species when intermediate forms appear to exist. This trouble has existed for some time now. Likely the first skeptic was Ostenfeld (1910) reporting on the existence of morphologically intermediate forms between those described as 'species' of Parafavella earlier by Brandt (1896). Later Schultz and Wulf $(1927,1929)$ in two large studies argued that there was but one species of Parafavella based on the variety of loricas found in the Barents Sea. Burkovsky (1973) postulated that lorica morphology of Parafavella changed seasonally in the White Sea. Gold and Morales (1975) documented a large variability in empty Parafavella lorica. The last concerted attempts to cast doubt on lorica-morphology based species boundaries in these common boreal tintinnids were studies by Davis concerning Parafavella (Davis 1978). His remarks echoed those of earlier researchers; Davis stated "... I experienced many vexations in attempting the classification of specimens." (Davis, 1978, p. 1823).

Adding to the troubles and confusion of those attempting to put names on forms is the fact that in the classic monograph on tintinnid ciliates, Kofoid and Campbell 1929, many of the illustrations are not drawn to the scale of the source illustrations (e.g., Figure S1 showing some Parafavella spp.). Thus investigators may assign different names to the same morphotype depending on apparent relative sizes (with no indication of variability) as shown in Kofoid and Campbell (1929) or the dimensions (and notes on variability) given in the original descriptions.

In recent years nuclear ribosomal genes have been applied to distinguish ciliate species and infer their phylogeny as DNA barcode (Pawlowski et al., 2012; Stoeck et al., 2014). Ciliates are suspected to contain a huge species diversity considering estimates of the numbers of as yet undescribed species (Foissner, 2008). 
An existing challenge is to separate closely related species efficiently using molecular methods. It has become apparent that $18 \mathrm{~S}$ rDNA, one of most common genes for ciliate taxonomy/phylogeny, appears to have an insufficient resolution for species identification. For instance, the $18 \mathrm{~S}$ rDNA is completely identical between some species of Tetrahymena (Lynn \& Strüder-Kypke, 2006) and shows more than 99.9\% genetic similarity between some congeners in Pleurotricha (Park et al., 2017). Because of the problematic resolution, there have been efforts to establish new genetic marker as a barcode for ciliates (Barth et al., 2006; Stoeck et al., 2014). For tintinnids, Santoferrara et al. (2013) assessed the nuclear genes as a potential barcoding tool, and she and colleagues (2016) suggested a guideline for data collection and evaluation. In addition, Santoferrara et al. (2015) reported the crypticity and polymorphism in the genus Helicostomella based on the ribosomal genes.

As mentioned by Santoferrara et al. (2016), the mitochondrial cytochrome $c$ oxidase subunit I (CO1) gene had not yet been amplified for the tintinnids. After the first report of intraspecific genetic variation using the CO1 in Paramecium (Barth et al., 2006), Strüder-Kypke and Lynn (2010) provided a primer pair, which successfully amplifies the $\mathrm{CO} 1$ from five ciliate classes. Considering its greater intraspecific variation than any nuclear genes, the $\mathrm{CO} 1 \mathrm{can}$ shed light on population genetics and biogeography. However, it should be noted that CO1 does not satisfy the CBOL (Consortium for the Barcode of Life)'s criteria as a barcode for all ciliates. Stoeck et al. (2014) noted that some ciliates from anoxic habitats lack active mitochondria and CO1. Furthermore, not all ciliate CO1 can be amplified using the existing CO1 primers (e.g. Litostomatea, Spirotrichea). Rather than as a ciliate barcode, the $\mathrm{CO} 1$ can be utilized for the seperation of closely related species or populations targeting specific ciliates. Park et al. (2018) provided a new primer pair, which can amplify the class Spirotrichea, and they successfully amplified Tintinnopsis cf. cylindrica. Here these new primers were applied to resolve the problematic situation among Parafavella forms.

To clarify the relationships among morphotypes of Parafavella, we employed single cell sequencing allowing us to investigate the genetic relationships of some more or less distinct morphotypes of Parafavella. We sequenced both nuclear ribosomal genes (28S rDNA, 18S rDNA, 5.8S rDNA, internal transcribed spacer regions: ITS1, ITS2) as well as mitochondrial CO1 sequences to group or distinguish 
morphotypes of Parafavella. We also investigated the co-occurrence of the more or less distinct morphotypes in natural populations by examining material from sites sampled in a transect from the North Pacific into the High Arctic in the summer of 2017.

\section{MATERIALS AND METHODS}

\subsection{Sampling}

For the genetic analysis, plankton net-tow samples were obtained from three distinct seas using $20-\mu \mathrm{m}$ mesh plankton net (for details, see Figure 1; Table 1). The samples were fixed with neutral Lugol's solution (final concentration of $0.04 \%$ iodine $[\mathrm{w} / \mathrm{v}]$; $0.6 \%$ potassium iodide $[\mathrm{w} / \mathrm{v}]$ ) or ethanol (final concentration of $70 \%$ ).

For the analysis of Parafavella forms found in natural assemblages of tintinnids, plankton net tow samples (20-mesh plankton net) obtained from stations along a transect from the North Pacific $\left(44^{\circ} \mathrm{N}\right)$ to the High Arctic $\left(78^{\circ} \mathrm{N}\right)$ sampled in July 2017 from aboard the Korean Icebreaker Araon were analyzed. Net tows sampled the water column from $100 \mathrm{~m}$ depth to the surface except at some shallow water stations. Aliquots of net tow material for microscopic analysis were fixed with Lugol's Iodine (as above) solution.

\subsection{Morphology}

For genetic analysis, individual cells were first isolated using a micro-capillary under a stereomicroscope (SZ11, Olympus, Japan), and micrographs were captured and measured under an inverted microscope (Eclipse Ti-U, Nikon, Japan) or standard microscopes (Zeiss Axio Imager 2 Carl Zeiss, Germany; BX53, Olympus, Japan) to record the morphology of the cells sequenced.

For analysis of the occurrence of forms of Parafavella in natural assemblages,, aliquots of net tow material from the 2017 sampling were diluted and examined in 3 $\mathrm{ml}$ settling chambers. Material in the settling chambers was examined using an Olympus inverted microscope (IX71) equipped with differential interference contrast optics and an Olympus DP71 camera piloted using Olympus Biocell imaging software. Initially all tintinnids in a single aliquot were enumerated. For samples in which 
Parafavella were found (samples from 9 stations), multiple aliquots were examined. For these latter samples, all Parafavella encountered which were correctly oriented for morphological diagnoses were photographed and multiple aliquots examined until a total of 20-30 cells from the sample were photographed. Only lorica containing a ciliate cell were recorded as empty lorica are not a reliable evidence of living cells (Dolan \& Yang, 2017). Parafavella "species" identification (based upon lorica morphology) were made relying as much as possible on illustrations and dimensions as given in the original descriptions (for details see "Parafavella "species" designations - taxonomic notes" in the Supplemental Files).

\subsection{DNA extraction, PCR, and DNA sequencing}

Each individual was transferred to $1.5 \mathrm{ml}$ tube and its genomic DNA was extracted using RED-Extract-N-Amp Tissue PCR Kit (Sigma, St. Louis, MO, USA) according to the manufacturer's instruction. Two PCRs were conducted to amplify nuclear ribosomal genes and mitochondrial CO1 gene. The conditions for the ribosomal genes were as follows: denaturation at 94 for $1 \mathrm{~min} 30 \mathrm{~s}$, followed by 40 cycles of denaturation at 98 for $10 \mathrm{~s}$, annealing at 58.5 for $30 \mathrm{~s}$, and extension at 72 for 3 min, and a final extension step at 72 for $7 \mathrm{~min}$. The PCR product that covered the genes consisting of 18S rDNA, internal transcribed spacer regions (ITS1, ITS2), 5.8S rDNA, and 28S rDNA (D1, D2) was amplified using slightly modified two primers (New Euk A and LSU rev2) that were described by Sonnenberg et al. (2007). DNA sequencing was performed using three additional internal primers (18SF790v2: 5' AAA TTA KAG TGT TYM ARG CAG-3' and 18SR300: 5'-CAT GGT AGT CCA ATA CAC TAC-3', 18SF1470: 5'-TCT GTG ATG CCC TTA GAT GTC-3') and an ABI 3700 sequencer (Applied Biosystems, Foster City, CA, USA). For the conditions of CO1, it was as follows: denaturation at 94 for $1 \mathrm{~min} 30 \mathrm{~s}$, followed by 40 cycles of denaturation at 98 for $10 \mathrm{~s}$, annealing at 53 for $30 \mathrm{~s}$, and extension at 72 for 1 min, and a final extension step at 72 for $7 \mathrm{~min}$ (for details and primers see Park et al., 2018). All PCR products were purified using a MEGAquick-spin Total Fragment DNA Purification Kit (iNtRON, Korea). Sequence fragments were assembled using Geneious 9.1.6 (Kearse et al., 2012).

\subsection{Molecular data analyses}


To infer the phylogenetic position of the four tintinnid species, 18S rRNA gene sequences of 199 ciliates were retrieved from the NCBI database, including 197 tintinnids and two oligotrichs, Novistrombidium orientale (FJ422988) and Strombidium stylifer (DQ631805), as outgroups. The sequences were aligned using Muscle alignment (Edgar, 2004) in Geneious, and both ends of the alignment were manually trimmed using the Geneious. The best-fit model of substitution for phylogenetic analysis was selected using jModelTest 2.1.10 (Darriba et al., 2012). We selected the model TIM2 + I (0.5690) + G (0.4550) for $18 \mathrm{~S}$ rDNA and HKY + I (0.6480) for CO1 based on the Akaike information criterion (AIC). As an outgroup of CO1 tree, Tintinnopsis cf. cylindrica (MG594903) was selected. IQ-TREE 1.5.3 was used to render maximum likelihood (ML) trees, with 1000 bootstrap replicates (Nguyen et al., 2015). A consensus ML tree was annotated using ggtree 1.8.2 in R (Yu et al., 2017). In addition, the tree using concatenated 28S rDNA, 5.8S rDNA and ITS regions was inferred with the best-fit model $\operatorname{TrN}+\mathrm{G}$ (0. 1040). Laackmanniella prolongata JQ924056 was selected as an outgroup. Uncorrected pairwise distances were measured using the Geneious.

To infer the median-joining network of CO1 haplotype, POPART 1.7 was used (Leigh \& Bryant, 2015). Input file includes the CO1 nucleotide sequences with its sampling location (latitude, longitude) to plot them in a map. The program assigned the CO1 sequences into each haplotype and plotted in default map.

In R, the ggplot2 (Wickham, 2009) was used to plot the 30 specimens annotated with its $\mathrm{CO} 1$ haplotype and species name to examine the relationship between the haplotypes and morphology. To represent sequence difference matrices, eight sequence data sets were set up to discern a resolution of species identification for Parafavella and they were as follows: 18S rDNA (1,745 bp), ITS1 (101 bp), 5.8S (152 bp), ITS2 (194 bp), 28S (D1, D2; 753 bp), 28S (D1, D2; 594 bp, shorter than previous one to make the sequences correspond with the reference sequence $P$. parumdentata), CO1 nucleotide (478 bp), and CO1 amino acids (159 aa) sequences. The sequence difference matrices measured by the Geneious were used to construct heatmaps using lattice in R (Sarkar, 2008).

\section{RESULTS}

\subsection{Lorica morphology of sequenced specimens}


Four morphotypes of Parafavella were collected from three distinct seas and here their lorica morphologies are described briefly (Figure 2; Table 1). See the Supplemental Document 1 for further details on distinguishing the morphotypes encountered.

Parafavella jorgenseni was collected from Bering Sea. Three specimens were sequenced: Lorica conical with reticulate surface, denticulate tilted outward on oral rim, 43.1-48.0 $\mu \mathrm{m}$ in lorica oral diameter (LOD), 96.7-106.3 $\mu \mathrm{m}$ in length, aboral end sharply pointed.

Parafavella gigantea was collected from the Bering Sea, Greenland Sea and East/Japan Sea. Twenty one specimens were sequenced: Lorica cylindrical/conical with reticulate surface, denticulate tilted outward on oral rim, 49.3-62.9 $\mu \mathrm{m}$ in LOD, 269.0-511.1 $\mu \mathrm{m}$ in length, aboral end pointed; in Bering and Greenland Sea specimens lorica usually cylindrical without indentation on oral rim, long cylindrical lorica with relatively shorter aboral end (vs. lorica more conical, aboral end longer with the indentation on oral rim in the East/Japan Sea specimens).

Parafavella greenlandica was collected from Greenland Sea. Two specimens were sequenced: Lorica conical with reticulate surface, denticulate tilted outward on oral rim, 33.2-34.8 $\mu \mathrm{m}$ in LOD, $78.4-86.4 \mu \mathrm{m}$ in length, aboral end somewhat bluntly pointed.

Parafavella subrotundata was collected from Bering Sea. Four specimens were examined and their morphology are as follows: Lorica cylindrical with reticulate surface and indentation on oral rim, denticulate tilted outward on oral rim, 57.4-63.4 $\mu \mathrm{m}$ in LOD, 163.2-250.8 $\mu \mathrm{m}$ in length, aboral end short and pointed; one of the examined specimens with aboral end being toward inside of lorica.

Two small morphotypes, $P$. greenlandica and $P$. jorgenseni, were easily separated from each other by the LOD (Table 1). In contrast, the other larger morphotypes, $P$. gigantea and $P$. subrotundata, share a similar size of LOD. In particular, $P$. gigantea was collected from all seas and they can be split into two morphotypes. The specimens from Bering and Greenland Sea usually have the largely cylindrical lorica without the indentation on oral rim, while the Korean population has the slightly conical lorica with the indentation on the oral rim. However, these 
characteristics are not distinct across whole specimens. See the specimens $P$. gigantea Arc07 and Arc09 had slightly conical lorica.

\subsection{Nuclear ribosomal genes}

A total of six data sets were analyzed to examine genetic relationships of the five morphotypes including $P$. parumdentata retrieved from GenBank (Figure 3). 18S and 5.8S gene sequences for the five species were completely identical (Figure 4A). It should be noted that one nucleotide difference in $18 \mathrm{~S}$ of $P$. parumdentata in Figure 3 denotes an ambiguous one (n).

ITS 1 and 2 yielded two clusters based on one (1.0\%) and five $(2.6 \%)$ nucleotide differences, respectively (Figure 3, 4B). The two clusters consist of $P$. greenlandica $+P$. parumdentata and $P$. jorgensen $i+P$. gigantea $+P$. subrotundata, that is the intra/inter-specific variations were $0 \%$ and $0-2.6 \%$, respectively.

$28 \mathrm{~S}$ data sets consist of two alignments because of the sequence length difference of $P$. parumdentata. The other sequences obtained newly here are longer than the $P$. parumdentata sequence in GenBank. Thus, the main differences between the data sets are the sequence length and absence/presence of $P$. parumdentata and so ' $28 \mathrm{~S}$ ' includes $753 \mathrm{bp}$ of 31 sequences and ' $28 \mathrm{~S}$ trimmed' includes $594 \mathrm{bp}$ of 30 sequences. Both data sets showed the same 3 clusters these clusters: 1) $P$. greenlandica + P. parumdentata, 2) P. gigantea (Greenland Sea), 3) P. gigantea (Bering Sea, East/Japan Sea) + P. subrotundata + P. jorgenseni. The intra/interspecific variations were $0-0.1 \%$ and $0-1.9 \%$ for ' $28 \mathrm{~S}$ ', and $0-0.2 \%$ and $0-2.4 \%$ for '28S trimmed'. The cluster 1, 'P. greenlandica and P. parumdentata', share completely identical nucleotide sequences except for the gap/deletion of a nucleotide in P. parumdentata. Except for the gap, this cluster differed at 12 (2.0\%) and 13 $(2.2 \%)$ nucleotide positions from $P$. gigantea (Greenland Sea) and $P$. gigantea (Bering Sea, East/Japan Sea) + P. subrotundata + P. jorgenseni, respectively. A single nucleotide of the cluster $P$. gigantea (Greenland Sea) differed from $P$. gigantea (Bering Sea, East/Japan Sea) and P. subrotundata and P. jorgenseni (Figure 3, 4B).

The data from concatenated 28S, 5.8S, ITS regions showed the same clusters as the $28 \mathrm{~S}$ data set because the cluster $P$. greenlandica $+P$. parumdentata based on ITS regions was completely identical to one of the three clusters based on the 
concatenated data and the $5.8 \mathrm{~S}$ sequences have no variations (Figure 4B). The three clusters from the concatenated did not reflect distinct geographical distribution.

\subsection{Mitochondrial CO1 gene}

CO1 nucleotide data showed eight haplotypes while the amino acids set were all completely identical to each other (Figures 3, 4C, D). Based on morphological identity, the intra/inter-specific variations of the nucleotide sequences were $0-9.4 \%$ and $0-18.2 \%$, respectively. The CO1 nucleotide sequence of Tintinnopsis cf. cylindrica as an outgroup showed inter-specific variations of $20.5-23.4 \%$ while the amino acid sequence showed $1.3 \%$ from those of Parafavella.

Parafavella gigantea consisted of four haplotypes that clustered in two groups: 1) Par07 + Par08 and 2) Par04 + Par05. These two groups had 43-45 nucleotide differences $(9.0 \%-9.4 \%)$ while each group had a single nucleotide difference $(0.2 \%)$ within them. The two sequences of $P$. greenlandica were completely identical and assigned to Par06. The three sequences of $P$. jorgensen $i$ split into three haplotypes. Of these, Par02 showed nine (1.9\%) nucleotide differences from Par03 while Par01 was highly distinct from Par02 + Par03 with $41(8.6 \%)$ or $42(8.8 \%)$ differences. Four sequences of $P$. subrotundata showed completely identical sequences with $P$. gigantea (East/Japan Sea) that assigned into Par07.

These eight haplotypes clustered into five groups based on the maximum likelihood tree and median-joining network using 97\% similarity threshold (Figure 4): Par01 (P. jorgenseni); Par02 + Par03 (P. jorgenseni); Par04 + Par05 (P. gigantea from Greenland Sea); Par06 (P. greenlandica); and Par07 + Par08 (P. gigantea from all three seas and $P$. subrotundata). As shown above, the barcode gap between intraand inter-specific variations was not observed.

\subsection{Biogeography of Parafavella based on genes}

Of the nuclear ribosomal genes, 28S and ITS regions showed nucleotide variations only within and among Parafavella morphotypes (Figure 4 B). One nucleotide difference was observed between the East/Japan Sea + the Bering Sea and the Greenland Sea for P. gigantea. The concatenated nucleotide sequences of Parafavella were completely identical within each population of the East/Japan and Bering Seas, respectively. Within the Greenland Sea population, two clusters were identified and 
each belongs to $P$. greenlandica and $P$. gigantea morphotype separated by 18 nucleotide differences.

Of the eight haplotypes in $\mathrm{CO} 1$, the Par07 was a common one and occurred from the all seas and groups $P$. gigantea with $P$. subrotundata (Figure 4D). The other haplotypes occurred only in one sea. Considering the number of haplotypes in each sea, the Greenland and Bering Sea showed the highest number of haplotypes as four (vs. 2 and 1 in ribosomal genes), respectively. However, the East/Japan Sea was represented by just two haplotypes, which have only one nucleotide difference (vs. identical in ribosomal genes). It should be noted that the nuclear ribosomal genes were too conserved to allow discrimination among populations compared to the $\mathrm{CO} 1$ as expected (Figure 4B). However, the eight haplotypes clustering into five groups resulted in neither distinct biogeography nor gradient distribution pattern (Figure 4D). See Figure 4D, the eight haplotypes (or the five clusters) did not show certain biogeography among haplotypes/clusters.

\subsection{Co-occurrence of distinct Parafavella morphotypes in natural communities}

Parafavella were found in 9 samples from the 2017 cruise of the Araon. None contained only a single morphotype. The number of different Parafavella "species" (based on differences in the loricas) ranged from 2 to 6 within individual samples. Table 2 data suggests that there was no apparent relationship between the number of Parafavella morphotypes found and latitude. Nor was a relationship between with the overall concentration of tintinnid ciliates or with the concentration of Parafavella cells and the number of morphotypes of Parafavella in a population (for details of the numbers and identities of Parafavella encountered see the Supplemental Plates 1-9).

\section{DISCUSSION}

\subsection{Nuclear ribosomal genes}

Previously, of all the species in Parafavella, nuclear gene data was available only for P. parumdentata (Santoferrara et al., 2017). As in their 18S tree, here all five species of Parafavella including four species from this study clustered together because all sequences of Parafavella are completely identical with the exception of a single nucleotide in $P$. parumdentata (ambiguous nucleotide n).and showed a sister 
relationship with a cluster " Dadayiella + Xystonella" Considering the five morphotypes in Parafavella, all nuclear ribosomal genes failed to distinguish among them. Even though the $28 \mathrm{~S}$ showed three clusters, it is still less than the numbers of morphotypes (5) based on lorica morphology and the CO1 nucleotide haplotypes (8). Of the nuclear genes, the $28 \mathrm{~S}$ has been considered as a useful barcoding tool for ciliates (Santoferrara et al., 2013; Stoeck et al., 2014). Santoferrara et al. (2013) separated tintinnids at $1 \%$ cutoff and Stoeck et al. (2014) identified that $<0.6 \%$ sequence divergence was ideal to separate Paramecium species. If we follow these thresholds, only two clusters were identified as follows: cluster 1 containing $P$. greenlandica and $P$. parumdentata the other cluster containing $P$. gigantea, $P$. subrotundata and P. jorgenseni. Among tintinnids, Helicostomella is one of the bestknown genera in terms of genetic data (Santoferrara et al., 2013, 2015; Xu et al., 2012). According to Santoferrara et al. (2015), use of these multi-gene barcodes (i.e., $28 \mathrm{~S}, 5.8 \mathrm{~S}-\mathrm{ITS}$ ) is better than using a single gene to distinguish closely related species. However we found that these multi-genes performed little better than a single gene marker in Parafavella yielding only two clusters. Nonetheless we agree with the comment of Santoferrara et al. (2015) that because CO1 is much more variable than these nuclear genes it results in lower resolution at higher level of phylogeny (Park et al., 2018). In addition, genetic diversity of the $\mathrm{CO} 1$ can originate from heteroplasmy (i.e., intracellular polymorphism of mitochondrial genomes), nuclear encoded mitochondrial pseudogenes, and hybrids (Tautz et al., 2003; Zhao et al., 2013)

The recent development of high-throughput sequencing technology has focused on attention on the variable regions (i.e., V4) in $18 \mathrm{~S}$ to capture eukaryote diversity (Filker et al., 2015; Jung et al., 2015; Santoferrara et al., 2018; Stoeck et al., 2010). However, our data supports the view that the nuclear ribosomal genes are of insufficient resolution below the genus level of Parafavella as shown in other tintinnids in previous reports (Santoferrara et al., 2013; Xu et al., 2012). In addition, there is evidence of low inter-specific variations in hypotrichs, benthic ciliates assigned to the ciliate class containing tintinnids (Park et al., 2017; Yi et al., 2008). Considering the $97-98 \%$ similarity threshold commonly used by the high-throughput approaches for the species richness, it would appear that only a part of eukaryote diversity is unveiled at least with regard to ciliates.

\subsection{Mitochondrial CO1 gene}


The CO1 of Parafavella was successfully amplified using the $\mathrm{CO} 1$ primers targeting spirotrichean ciliates (Park et al., 2018). Even though they provided only the CO1 of Tintinnopsis cf. cylindrica among tintinnids, our study suggests that other tintinnids could be sequenced using the primers. Strüder-Kypke and Lynn (2010) established new primers to amplify the $\mathrm{CO} 1$ of ciliates, however, as they mentioned, they did not reliably amplify Litostomatea and Spirotrichea. The CO1 of Parafavella overlaps 260-348 bp with those region from Strüder-Kypke and Lynn (2010). Across all sequences of Parafavella, none of indels occurred that resulted in frame shifts or be considered as nuclear encoded mitochondrial pseudogenes (Zhao et al., 2013).

The CO1 sequences of Parafavella showed higher genetic variation than the nuclear ribosomal genes, up to $18.2 \%$ in inter-specific variations. Considering the maximum of the inter-specific variations in the $28 \mathrm{~S}$, the CO1 showed the variations higher than seven times in Parafavella. A total of eight haplotypes were identified based on the CO1 nucleotide sequences that resulted in five clusters using $97 \%$ similarity threshold. If we follow the $<1 \%$ intra-specific divergence as shown by Lynn and Strüder-Kypke (2006) and Chantangsi et al. (2007), six clusters can be identified because $P$. jorgenseni Ara02 and Ara03 have nine nucleotide differences between them $(1.9 \%)$.

\subsection{Lorica morphology with CO1 haplotypes}

The species designations of Parafavella have been contentious because of suspected lorica variability (Davis, 1978; Kofoid \& Campbell, 1929; Schulz \& Wulff, 1929). Kofoid and Campbell (1929) established the genus and assigned species status to 23 forms, most of which had been described originally as variants of other species. The most recent compendium of Zhang et al. (2012) lists 32 species found in the literature. In the WoRMS database (Warren, 2018), 35 species are listed including 6 as 'taxon inquirendum', suspected of being variants of other species.

Davis (1978) tried to distinguish Parafavella species collected from northern Norway waters, however he failed to distinguish them based on lorica morphology alone. Even though some previous works considered them as a single polymorphic species ( $P$. denticulata), he emphasized the need for further investigation of this genus using methods such as silver staining, electron microscopy, and etc. Here, we found six clusters based the $1 \%$ cutoff value from the eight CO1 haplotypes. The results 
clearly showed that 1) $P$. subrotundata has identical nucleotide sequence with $P$. gigantea; 2) P. gigantea includes two clusters; 3) P. jorgenseni can be split into three clusters; and 4) P. greenlandica is distinct from the others.

Parafavella subrotundata collected from the Bering Sea showed completely identical sequences with $P$. gigantea in Par07, which is the most common haplotype across the three seas. Kofoid and Campbell (1929) considered that $P$. subrotundata 'differs from $P$. cylindrica in stouter proportions and from $P$. dilatata in less conical bowl'. Based on our CO1 haplotypes, the results suggest that the cylindrical forms in Parafavella might be assigned to $P$. gigantea.

Of the specimens in our samples, we have $P$. gigantea with slightly posteriorly dilated lorica like P. ventricosa (see Arc02, Arc05, Arc08, Ara08). Even though the dilated form was not as distinct as shown in Kofoid and Campbell (1929), it suggests they might be conspecific.

Based on the tintinnids records reported in the Arctic Seas by Dolan et al. (2017), Parafavella denticulata is the most commonly reported species in this genus. Even though we did not obtain the CO1 sequence from $P$. denticulata, it might be assigned to $P$. gigantea $\mathrm{CO} 1$ clusters like $P$. subrotundata.

Interestingly, the 2 species with short conical lorica, $P$. greenlandica and $P$. jorgenseni, did not cluster together and $P$. greenlandica was distinct from the other species in Parafavella. This finding suggests that the size and shape of the lorica are poor predictors of genetic relatedness in Parafavella. Considering the utility of oral denticulation in distinguishing species, we observed some $P$. gigantea with the denticulation, which was almost disconnected from the oral rim during the examination using the scanning electron microscopy (Figure S2). We also found $P$. gigantea without denticulation in Lugol's-fixed samples (see supplemental Plate 3 ARA08 St4A) in agreement with the observations of Davis (1978). Thus, oral denticulation does not appear to be reliable character among Parafavella. To date, data on the infraciliature of Parafavella are available only for P. denticulata and $P$. gigantea (Pierce, 1996). As mentioned by Santoferrara et al. (2016), infraciliature patterns can shed light on their biodiversity. Unfortunately, commercial production of protargol, the key chemical for protargol staining to examine infraciliature, has ended. We have tried to stain Parafavella using laboratory-synthesized protargol (Kim \& 
Jung, 2017), but the stain quality was poor for the cells stored for a lengthy time in Bouin's solution. We recommend a focus on the infraciliature of representative haplotypes after screening the $\mathrm{CO} 1$ haplotypes rather than examining the infraciliature of all morphotypes.

\subsection{Co-occurrence of distinct Parafavella morphotypes in natural communities}

We found as many as 6 morphotypes, classically distinguished as distinct species, in a single sample. It is important to note that while many previous studies documented the co-occurrence of distinct lorica types of Parafavella (e.g. Ostenfeld, 1910; Schulz \& Wulff, 1927, 1929; Burkovsky, 1973; Davis, 1978) ours is the first study to rely solely on lorica containing ciliate cells. Empty tintinnid lorica are poor indicators of the occurrence and morphology of living tintinnids (Dolan \& Yang, 2017; Kato \& Taniguichi, 1993). However, it unclear what factors may influence the occurrence of distinct morphotypes of Parafavella. There was no obvious relationship between the number of morphotypes found and location in the form of latitude. Notably there was no relationship between the number of morphotypes and either the concentration neither of Parafavella cells nor with concentrations of total tintinnids (Table 1).

Our findings with regard to the occurrence of Parafavella morphotypes contrast to findings with regard to Cymatocylis in Antarctic waters. Like Parafavella of boreal waters, Kim et al. (2013) found different morphotypes of Cymatocylis of the Southern Ocean microzooplankton, previously considered as distinct species, to be variants of a single species. The number of different morphotypes found in populations in the Amundsen Sea was unrelated to the concentration or composition of their phytoplankton prey but was positively related to the concentration of Cymatocylis cells (Dolan et al., 2013). Culture work with Favella showed that lorica construction by a newly divided cell is rapid (2-10 minutes) and the length and shape of the lorica constructed appears to depend on the amount lorica material within the newly-divided ciliate cell (reviewed in Agatha et al., 2013). It was then hypothesized that co-occurrence of multiple morphotypes of Cymatocylis reflected periods of rapid population growth with variable morphotypes formed by rapidly reproducing cells. This does not appear to be the case in Parafavella, as the number of morphotypes found in a population was not related to the concentration of Parafavella. At this time 
we can offer no explanation for the apparent polymorphism of certain haplotypes of Parafavella.

\section{ACKNOWLEDGEMENTS}

This work was supported by grants from the National Research Foundation of Korea (NRF) funded by the Korea government (MSIP; Ministry of Science, ICT \& Future Planning) (No. NRF-2017R1C1B5017183), and the Korea Polar Research Institute (KOPRI)[grant number PE17900]. Partial support was provided by grants from the KAOOS program (KOPRI; PM18040 \& 20160245) funded by the MOF, Korea.

\section{REFERENCES}

Agatha, S., Laval-Peuto, \& M. Simon, P. (2013). The tintinnid lorica. in Biology and Ecology of Tintinnid Ciliates: Models for Marine Plankton, Dolan, J.R., Agatha, S., Coats, D.W., Montagnes, D.J.S., Stocker, D.K. (eds). Wiley-Blackwell, Oxford, pp 17-41

Barth, D., Krenek, S., Fokin, S. I., \& Berendonk, T. U. (2006). Intraspecific genetic variation in Paramecium revealed by mitochondrial cytochrome $c$ oxidase I sequences. Journal of Eukaryotic Microbiology 53, 20-25

Brandt, K. (1896). Die Tintinnen. Bibliotheca Zoologica, 20, 45-72

Burkovsky, I. V. (1973). Variability of Parafavella denticulata in the White Sea. Zoologicheskiy zhurnal, 52, 1277-1285

Chantangsi, C., Lynn, D.H., Brandl, M.T., Cole, J.C., Hetrick, N., \& Ikonomi, P. (2007). Barcoding ciliates: a comprehensive study of 75 isolates of the genus Tetrahymena. International Journal of Systematic and Evolutionary Microbiology, 57, 2412-2425

Darriba, D., Taboada, G.L., Doallo, R., \& Posada, D. (2012). jModelTest 2: more models, new heuristics and parallel computing. Nature Methods 9, 772

Davis, C. C. (1978). Variations of the lorica in the genus Parafavella (Protozoa: Tintinnida) in northern Norway waters. Canadian Journal of Zoology 56, 18221827

Deepayan, S. (2008) Lattice: Multivariate data visualization with R. Springer, New 
York

Dolan, J. R., \& Yang, E. J. (2017). Observations of apparent lorica variability in Salpingacantha (Ciliophora: Tintinnida) in the Northern Pacific and Arctic Oceans. Acta Protozoologica, 56, 217-220

Dolan, J. R., Yang, E. J., Lee, S. H., \& Kim, S.Y. (2013). Tintinnid ciliates of the Amundsen Sea (Antarctica) Plankton Communities. Polar Research, 32, 19784

Dolan, J. R., Pierce, R. W., \& Yang, E. J. (2017). Tintinnid ciliates of the marine microzooplankton in Arctic Seas: a compilation and analysis of species records. Polar Biology, 40, 1247-1260

Edgar, R. C. (2004). MUSCLE: multiple sequence alignment with high accuracy and high throughput. Nucleic Acids Research, 32, 1792-1797

Filker, S., Gimmler, A., Dunthorn, M., Mahé, F., \& Stoeck, T. (2015). Deep sequencing uncovers protistan plankton diversity in the Portuguese Ria Formosa solar saltern ponds. Extremophiles, 19, 283-295.

Foissner, W., Chao, A., \& Katz, L. A. (2008). Diversity and geographic distribution of ciliates (Protista: Ciliophora). Biodiversity and Conservation, 17, 345-363

Gold, K. \& Morales, E.A. (1975) Tintinnida of the New York Bight: Loricae of Parafavella gigantea, P. parundentata, and Ptychocylis obtusa. Transactions of the American Microscopical Society 94, 142-145.

Jörgensen, E. (1900). Ueber die Tintinnodeen der norwegischen Westküste. Bergens Museums Aarbog for 1899, no. 2., 1-48

Jørgensen, E. (1905). Protistenplankton aus dem Nordmeere in dem Jahren 18971900. Bergens Museums Aarbog 1900, No. VI, 37 pp

Jung, J.-H., Park, K.-M., Yang, E. J., Joo, H. M., Jeon, M., Kang, S.-H., Choi, H.-G., Park, M.-H., Min, G.-S., \& Kim, S. (2015). Patchy-distributed ciliate (Protozoa) diversity of eight polar communities as determined by 454 amplicon pyrosequencing. Animal Cells and Systems, 19, 339-349

Kato, S., \& Taniguichi, A. (1993). Tintinnid ciliates as indicator species of different water masses in the western North Pacific Polar Front. Fisheries Oceanography, $2,166-174$

Kearse, M., Moir, R., Wilson, A., Stones-Havas, S., Cheung, M., Sturrock, S., Buxton, S., Cooper, A., Markowitz, S., Duran, C., Thierer, T., Ashton, B., Mentjies, P., \& Drummond, A. (2012). Geneious Basic: an integrated and extendable desktop 
software platform for the organization and analysis of sequence data.

Bioinformatics, 28, 1647-1649

Kim, J. H., \& Jung, J.-H. (2017). Cytological staining of protozoa: A case study on the impregnation of hypotrichs (Ciliophora: Spirotrichea) using laboratorysynthesized protargol. Animal Cells and Systems, 21, 412-418

Kim, S. Y., Choi, J. K., Dolan, J. R., Shin, H. C., Lee, S., \& Yang, E. J. (2013). Morphological and ribosomal DNA-based characterization of six Antarctic ciliate 5 morphopecies from the Amundsen Sea with phylogenetic analyses. Journal of Eukaryotic Microbiology, 60, 497-513

Kofoid, C. A., \& Campbell, A. S. (1929). A conspectus of the marine and freshwater Ciliata belonging to the suborder Tintinnoinea, with descriptions of new species principally from the AGASSIZ expedition to the eastern tropical Pacific, 19041905. University of California Publications in Zoology, 34, 1-403

Leigh, J. W., \& Bryant, D. (2015). POPART: full-feature software for haplotype network construction. Methods in Ecology and Evolution, 6, 1110-1116

Lovejoy, C., von Quillfeldt, C., Hopcroft, R. R., Poulin, M., Mary Thaler, M., Arendt, K., Debes, H., Gíslason, Á., \& Kosobokova, K. (2017). "Plankton" in CAFF. 2017. State of the Arctic marine biodiversity: Key findings and advice for monitoring. conservation of Arctic flora and fauna" International Secretariat, Akureyri, Iceland. ISBN: 978-9935-431-62-2 (available at www.arcticbiodiversity.is/marine)

Lynn, D. H., \& Strüder-Kypke, M. C. (2006). Species of Tetrahymena identical by small subunit rRNA gene sequences are discriminated by mitochondrial cytochrome $c$ oxidase I gene sequences. Journal of Eukaryotic Microbiology, 53, $385-387$

Nguyen, L.-T., Schmidt, H. A., von Haeseler, A., Minh, B. Q. (2015). IQ-TREE: A fast and effective stochastic algorithm for estimating maximum-likelihood phylogenies. Molecular Biology and Evolution, 32, 268-274

Ostenfeld, C. H. (1910). Marine plankton from the East-Greenland Sea (W. of $6^{\circ} \mathrm{W}$. long. and N. of $73^{\circ} 30^{\prime}$ N. lat.) collected during the Danmark Expedition 19061908: II Protozoa. Danmark-Ekspeditionen til Gronlands Nordostkyst 1906-1908, 3, 287-300.

Park, M.-H., Moon, J. H., Kim, K. N., \& Jung, J.-H. (2017). Morphology, 
morphogenesis, and molecular phylogeny of Pleurotricha oligocirrata nov. spec. (Ciliophora: Spirotrichea: Stylonychinae). European Journal of Protistology, 59, $114-123$

Park, M.-H., Jung, J.-H., Jo, E., Park, K.-M., Baek, Y.-S., Kim, S.-J., \& Min, G.-S., (2018). Utility of mitochondrial CO1 sequences for species discrimination of Spirotrichea ciliates (Protozoa, Ciliophora). Mitochondrial DNA Part A, DOI:10.1080/24701394.2018.1464563.

Pawlowski, J., Audic, S., Adl, S., Bass, D., Belbahri, L., Berney, C., Bowser, S. S., Cepicka, I., Decelle, J., Dunthorn, M., Fiore-Donno, A. M., Gile, G. H., Holzmann, M., Jahn, R., Jirků, M., Keeling, P. J., Kostka, M., Kudryavtsev, A., Lara, E., Lukeš, J., Mann, D. G., Mitchell, E. A. D., Nitsche, F., Romeralo, M., Saunders, G. W., Simpson, A. G. B., Smirnov, A. V., Spouge, J. L., Stern, R. F., Stoeck, T., Zimmermann, J., Schindel, D., \& de Vargas, C. (2012). CBOL protist working group: Barcoding eukaryotic richness beyond the animal, plant, and fungal kingdoms. PLoS Biology, 10, e1001419

Pierce, R. W. (1996). Morphology and infraciliature of selected species of Tintinnina with a phylogenetic analysis of the Tintinnina based on infraciliature.

Dissertation, University of Rhode Island, Rhode Island, USA

Sarkar, D. (2008) Lattice: Multivariate data visualization with R. Springer, New York Santoferrara, L. F., McManus, G. B., \& Alder, V. A. (2013). Utility of genetic markers and morphology for species discrimination within the order Tintinnida (Ciliophora, Spirotrichea). Protist, 164, 24-36

Santoferrara, L. F., Alder, V. V., \& McManus, G. B. (2017). Phylogeny, classification and diversity of Choreotrichia and Oligotrichia (Ciliophora, Spirotrichea). Molecular Phylogenetics and Evolution, 112, 12-22

Santoferrara, L. F., Rubin, E., \& McManus, G. B. (2018). Global and local DNA (meta)barcoding reveal new biogeography patterns in tintinnid ciliates. Journal of Plankton Research, DOI:10.1093/plankt/fby011

Santoferrara, L. F., Tian, M., Alder, V. A., \& McManus, G. B. (2015). Discrimination of closely related species in tintinnid ciliates: New insights on crypticity and polymorphism in the genus Helicostomella. Protist 166, 78-92

Santoferrara, L. F., Bachy, C., Alder, V. A., Gong, J., Kim, Y.-O., Saccà, A., da Silva Neto, I. D., Strüder-Kypke, M. C., Warren, A., Xu, D., Yi, Z., \& Agatha, S. 
(2016). Updating biodiversity studies in loricate protists: The case of the tintinnids (Alveolata, Ciliophora, Spirotrichea). Journal of Eukaryotic Microbiololgy, 63, 651-656

Schulz, B., \& Wulff, A. (1927). Hydrographische und planktologische Ergebnisse der Fahrt des Fischereischutzbootes "Zeiten" in das Barentsmeer im AugustSeptember 1926. Die Berichte der Deutschen Wissenschaftlichen Kommission für Meeresforschung, 3, 211-280

Schulz, B., \& Wulff, A. (1929). Hydrographie und Oberflächenplankton des Westlichen Barentsmeeres im Sommer 1927. Ber Deutsch Wissensch Komm Meeresforsch, 4, 7-141

Sonnenberg, R., Nolte, A. W., \& Tautz, D. (2007). An evaluation of LSU rDNA D1D2 sequences for their use in species identification. Frontiers in Zoology, 4, 6 Stoeck, T., Przybos, E., \& Dunthorn, M. (2014). The D1-D2 region of the large subunit ribosomal DNA as barcode for ciliates. Molecular Ecology Resources, 14, $458-468$

Stoeck, T., Bass, D., Nebel, M., Christen, R., Jones, M. D. M., Breiner, H.-W., \& Richards, T.A. (2010). Multiple marker parallel tag environmental DNA sequencing reveals a highly complex eukaryotic community in marine anoxic water. Molecular Ecology, 19, 21-31

Strüder-Kypke, M. C., \& Lynn, D. H. (2010). Comparative analysis of the mitochondrial cytochrome $c$ oxidase subunit I (COI) gene in ciliates (Alveolata, Ciliophora) and evaluation of its suitability as a biodiversity marker. Systematics and Biodiversity, 8, 131-148

Tautz, D., Arctander, P., Minelli, A., Thomas, R. H., \& Vogler, A. P. (2003). A plea for DNA taxonomy. Trends in Ecology \& Evolution, 18, 70-74

Warren, A., (2018). World Ciliophora Database. Parafavella Kofoid \& Campbell, 1929. Accessed through: World Register of Marine Species at: http://www.marinespecies.org/aphia.php?p=taxdetails\&id=196836 on 2018-0501

Wickham, H. (2009). ggplot2: Elegant Graphics for Data Analysis. Springer-Verlag New York

Xu, D., Sun, P., Shin, M. K., \& Kim, Y. O. (2012). Species boundaries in tintinnid ciliates: A case study - morphometric variability, molecular characterization, and 
temporal distribution of Helicostomella species (Ciliophora, Tintinnina). Journal of Eukaryotic Microbiology, 59, 351-358

Yi, Z., Chen, Z., Warren, A., Roberts, D., Al-Rasheid, K., Miao, M., Gao, S., Shao, C., \& Song, W. (2008). Molecular phylogeny of Pseudokeronopsis (Protozoa, Ciliophora, Urostylida), with reconsideration of three closely related species at inter-and intra-specific levels inferred from the small subunit ribosomal RNA gene and the ITS1-5.8 S-ITS2 region sequences. Journal of Zoology, 275, 268275

Yu, G., Smith, D. K., Zhu, H., Guan, Y., \& Lam, T. T.-Y. (2017). ggtree: an R package for visualization and annotation of phylogenetic trees with their covariates and other associated data. Methods in Ecology and Evolution, 8, 2836

Zhang, W., Feng, M., Yu, Y., Zhang, C., \& Xiao, T. (2012). An illustrated guide to contemporary tintinnids in the world. Science Press, Beijing

Zhao, Y., Gentekaki, E., Yi, Z., \& Lin, X. (2013). Genetic differentiation of the mitochondrial cytochrome oxidase $c$ subunit I gene in genus Paramecium (Protista, Ciliophora). PLoS ONE, 8, e77044 
Table 1. List of species analyzed in this study with morphological and DNA sequences data.

\begin{tabular}{|c|c|c|c|c|c|c|c|}
\hline \multirow[t]{2}{*}{ Species } & \multirow[t]{2}{*}{ Isolate } & \multicolumn{2}{|c|}{ Sampling data } & \multicolumn{2}{|c|}{ Measurements } & \multirow{2}{*}{$\begin{array}{l}\text { SSU rDNA-ITS regions-LSU } \\
\text { rDNA }(2,945 \mathrm{bp})\end{array}$} & \multirow[b]{2}{*}{$\begin{array}{l}\text { COI gene }(478 \\
\text { bp) }\end{array}$} \\
\hline & & Date & Latitude/longitude & $\begin{array}{l}\text { Lorica oral } \\
\text { diameter }\end{array}$ & Length & & \\
\hline P. jorgenseni & Ara01 & $7 / 24 / 2012$ & N54¹9'59.4"/E173³9'58.8" (Bering Sea) & 43.1 & 96.7 & XXXXXXXX & XXXXXXXX \\
\hline P. jorgenseni & Ara02 & $7 / 24 / 2012$ & N54¹9'59.4"/E173³9'58.8" (Bering Sea) & 48.0 & 106.3 & XXXXXXXX & XXXXXXXX \\
\hline P. jorgenseni & Ara03 & $7 / 24 / 2012$ & N5419'59.4"/E173³9'58.8" (Bering Sea) & 46.2 & 105.7 & XXXXXXXX & XXXXXXXX \\
\hline $\begin{array}{l}P . \\
\text { subrotundata }\end{array}$ & Ara04 & $7 / 26 / 2012$ & N58 $48^{\prime} 10.2^{\prime \prime} / \mathrm{W} 178^{\circ} 29^{\prime} 41.4^{\prime \prime}$ (Bering Sea) & 60.6 & 250.8 & XXXXXXXX & XXXXXXXX \\
\hline $\begin{array}{l}P . \\
\text { subrotundata }\end{array}$ & Ara05 & $7 / 26 / 2012$ & N58 $45^{\prime} 10.2^{\prime \prime} / \mathrm{W} 178^{\circ} 29^{\prime} 41.4^{\prime \prime}$ (Bering Sea) & 62.6 & 163.2 & XXXXXXXX & XXXXXXXX \\
\hline $\begin{array}{l}P . \\
\text { subrotundata }\end{array}$ & Ara06 & $7 / 26 / 2012$ & N58 $45^{\prime} 10.2^{\prime \prime} / \mathrm{W} 178^{\circ} 29^{\prime} 41.4^{\prime \prime}$ (Bering Sea) & 63.4 & 186.8 & XXXXXXXX & XXXXXXXX \\
\hline $\begin{array}{l}P . \\
\text { subrotundata }\end{array}$ & Ara07 & $7 / 26 / 2012$ & N5845'10.2"/W178²9'41.4" (Bering Sea) & 57.4 & 202.8 & XXXXXXXX & XXXXXXXX \\
\hline P. gigantea & Ara08 & $7 / 27 / 2012$ & N62³0'35.4"/W17359'54.0" (Bering Sea) & 67.0 & 515.6 & XXXXXXXX & XXXXXXXX \\
\hline P. gigantea & Arc01 & $7 / 23 / 2017$ & N78 $55^{\prime} 42.5^{\prime \prime} / \mathrm{E} 11^{\circ} 56^{\prime} 18.5^{\prime \prime}$ (Greenland Sea) & 59.0 & 399.8 & XXXXXXXX & XXXXXXXX \\
\hline P. gigantea & $\mathrm{Arc} 02$ & $7 / 23 / 2017$ & N78 $55^{\prime} 42.5^{\prime \prime} / \mathrm{E} 11^{\circ} 56^{\prime} 18.5^{\prime \prime}$ (Greenland Sea) & 60.1 & 390.5 & XXXXXXXX & XXXXXXXX \\
\hline P. gigantea & $\mathrm{Arc03}$ & $7 / 23 / 2017$ & N78 $55^{\prime} 42.5^{\prime \prime} / \mathrm{E} 11^{\circ} 56^{\prime} 18.5^{\prime \prime}$ (Greenland Sea) & 62.9 & 415.0 & XXXXXXXX & XXXXXXXX \\
\hline P. gigantea & Arc04 & $7 / 23 / 2017$ & N78 $55^{\prime} 42.5^{\prime \prime} / \mathrm{E} 11^{\circ} 56^{\prime} 18.5^{\prime \prime}$ (Greenland Sea) & 60.6 & 426.8 & XXXXXXXX & XXXXXXXX \\
\hline P. gigantea & $\mathrm{Arc} 05$ & $7 / 23 / 2017$ & N78 $55^{\prime} 42.5^{\prime \prime} / \mathrm{E} 11^{\circ} 56^{\prime} 18.5^{\prime \prime}$ (Greenland Sea) & 61.6 & 366.0 & XXXXXXXX & XXXXXXXX \\
\hline P. gigantea & Arc06 & $7 / 23 / 2017$ & N78 $55^{\prime} 42.5^{\prime \prime} / \mathrm{E} 11^{\circ} 56^{\prime} 18.5^{\prime \prime}$ (Greenland Sea) & 58.7 & 511.1 & XXXXXXXX & XXXXXXXX \\
\hline P. gigantea & Arc07 & $7 / 23 / 2017$ & N78 $55^{\prime} 42.5^{\prime \prime} / \mathrm{E} 11^{\circ} 56^{\prime} 18.5^{\prime \prime}$ (Greenland Sea) & 49.3 & 360.4 & XXXXXXXX & XXXXXXXX \\
\hline P. gigantea & Arc08 & $7 / 23 / 2017$ & N78 $55^{\prime} 42.5^{\prime \prime} / \mathrm{E} 11^{\circ} 56^{\prime} 18.5^{\prime \prime}$ (Greenland Sea) & 54.5 & 452.4 & XXXXXXXX & XXXXXXXX \\
\hline P. gigantea & Arc09 & $7 / 23 / 2017$ & N78 $55^{\prime} 42.5^{\prime \prime} / \mathrm{E} 11^{\circ} 56^{\prime} 18.5^{\prime \prime}$ (Greenland Sea) & 58.2 & 419.1 & XXXXXXXX & XXXXXXXX \\
\hline P. gigantea & Arc10 & $7 / 23 / 2017$ & N78 $55^{\prime} 42.5^{\prime \prime} / \mathrm{E} 11^{\circ} 56^{\prime} 18.5^{\prime \prime}$ (Greenland Sea) & 52.1 & 277.9 & XXXXXXXX & XXXXXXXX \\
\hline $\begin{array}{l}P . \\
\text { greenlandica }\end{array}$ & Arc11 & $7 / 14 / 2017$ & N78 $55^{\prime} 40.9^{\prime \prime} / \mathrm{E} 11^{\circ} 56^{\prime} 11.8^{\prime \prime}$ (Greenland Sea) & 34.8 & 86.4 & XXXXXXXX & XXXXXXXX \\
\hline $\begin{array}{l}P . \\
\text { greenlandica }\end{array}$ & Arc12 & $7 / 14 / 2017$ & N78 $55^{\prime} 40.9^{\prime \prime} / \mathrm{E} 11^{\circ} 56^{\prime} 11.8^{\prime \prime}$ (Greenland Sea) & 33.2 & 78.4 & XXXXXXXX & XXXXXXXX \\
\hline P. gigantea & Kor01 & $5 / 23 / 2016$ & N3704'18.4"/E12857'5.6" (East/Japan Sea) & 57.8 & 285.3 & XXXXXXXX & XXXXXXXX \\
\hline P. gigantea & Kor02 & $3 / 11 / 2016$ & N3752'1.0"/E12850'54.4" (East/Japan Sea) & 60.9 & 378.9 & XXXXXXXX & XXXXXXXX \\
\hline P. gigantea & Kor03 & $3 / 3 / 2016$ & N38 $8^{\circ} 18.1^{\prime \prime} / \mathrm{E} 128^{\circ} 36^{\prime} 34.1^{\prime \prime}$ (East/Japan Sea) & 61.6 & 376.1 & XXXXXXXX & XXXXXXXX \\
\hline P. gigantea & Kor04 & $3 / 11 / 2016$ & N37²6'18.4"/E12857'5.6" (East/Japan Sea) & 59.6 & 269.0 & XXXXXXXX & XXXXXXXX \\
\hline
\end{tabular}


Table 2. Numbers of different morphological species of Parafavella found in samples taken from the sites between the North Pacific and the Arctic in July 2017. Note the wide range of natural communities sampled in terms of concentrations of Parafavella and total tintinnids ( $\sum$ tintinnids).

\begin{tabular}{|c|c|c|c|c|c|c|c|}
\hline Station & Lat & Long & Date & Parafavella $1^{-1}$ & $\sum$ tintinnids $1^{-1}$ & \# "spp" & Suppl Plate \\
\hline ARA08A01 & 42.3 & 151.2 & $\begin{array}{l}7 / 27 / \\
2017\end{array}$ & 0.4 & 1.2 & 4 & 1. ARA08 St 1A \\
\hline ARA08A03 & 46.6 & 159.4 & $\begin{array}{l}7 / 29 / \\
2017\end{array}$ & 0.3 & 2.3 & 4 & 2. ARA08 St 3A \\
\hline ARA08A04 & 48.9 & 163.5 & $\begin{array}{l}7 / 29 / \\
2017\end{array}$ & 0.5 & 4.7 & 3 & 3. ARA08 St 4A \\
\hline ARA08A05 & 51.1 & 167.6 & $\begin{array}{l}7 / 29 / \\
2017\end{array}$ & 0.2 & 2.4 & 4 & 4. ARA08 St 5A \\
\hline ARA08A06 & 53.1 & 171.6 & $\begin{array}{l}7 / 30 / \\
2017\end{array}$ & 10.5 & 283.8 & 2 & 5. ARA08 St 6A \\
\hline ARA08A07 & 55.1 & 175.7 & $\begin{array}{l}7 / 31 / \\
2017\end{array}$ & 0.8 & 16.8 & 2 & 6. ARA08 St 7A \\
\hline ARA08B02 & 66.6 & -167.3 & $\begin{array}{l}8 / 7 / 2 \\
017\end{array}$ & 10.2 & 165.6 & 6 & 7. ARA08 St 2B \\
\hline ARA08B08 & 68.2 & -166.9 & $\begin{array}{l}8 / 7 / 2 \\
017\end{array}$ & 6.0 & 108.9 & 4 & 8. ARA08 St 8B \\
\hline ARA08B21 & 77.7 & 180.0 & $\begin{array}{l}8 / 15 / \\
2017\end{array}$ & 0.1 & 0.2 & 3 & 9. ARA08 St 21B \\
\hline
\end{tabular}




\begin{tabular}{|c|c|c|c|c|c|c|c|}
\hline P. gigantea & Kor05 & $3 / 11 / 2016$ & N37²6'18.4"/E12857'5.6" (East/Japan Sea) & 60.8 & 434.2 & XXXXXXXX & XXXXXXXX \\
\hline P. gigantea & Kor06 & $3 / 11 / 2016$ & N3746'18.4"/E12857'5.6" (East/Japan Sea) & 62.6 & 416.9 & XXXXXXXX & $\mathrm{XXXXXXXX}$ \\
\hline P. gigantea & Kor07 & $3 / 11 / 2016$ & N37²6'18.4"/E12857'5.6" (East/Japan Sea) & 61.7 & 375.6 & XXXXXXXX & XXXXXXXX \\
\hline P. gigantea & Kor08 & $3 / 11 / 2016$ & N3704'18.4"/E12857'5.6" (East/Japan Sea) & 61.0 & 348.4 & XXXXXXXX & XXXXXXXX \\
\hline P. gigantea & Kor09 & $3 / 11 / 2016$ & N37²6'18.4"/E12857'5.6" (East/Japan Sea) & 60.8 & 312.0 & XXXXXXXX & $\mathrm{XXXXXXXX}$ \\
\hline P. gigantea & Kor10 & $3 / 11 / 2016$ & N3746'18.4"/E12857'5.6" (East/Japan Sea) & 59.7 & 295.5 & XXXXXXXX & XXXXXXXX \\
\hline
\end{tabular}




\section{Figure legends}

Fig. 1. Map of the locations sampled from three different seas. The numbers in parenthesis denote the number of specimens sequenced in this study. The haplotype represents $\mathrm{CO} 1$ nucleotide diversity.

Fig. 2. Micrographs of four Parafavella species all at the the same magnification.

Fig. 3. Heatmaps based on genetic dissimilarities.

Fig. 4. Maximum likelihood phylogenetic trees and median-joining network. The network was constructed using $\mathrm{CO} 1$ nucleotide sequences.

Fig. 5. Morphological characteristics and CO1 nucleotide haplotypes of four Parafavella species. 


\section{- $72 a^{2}$}




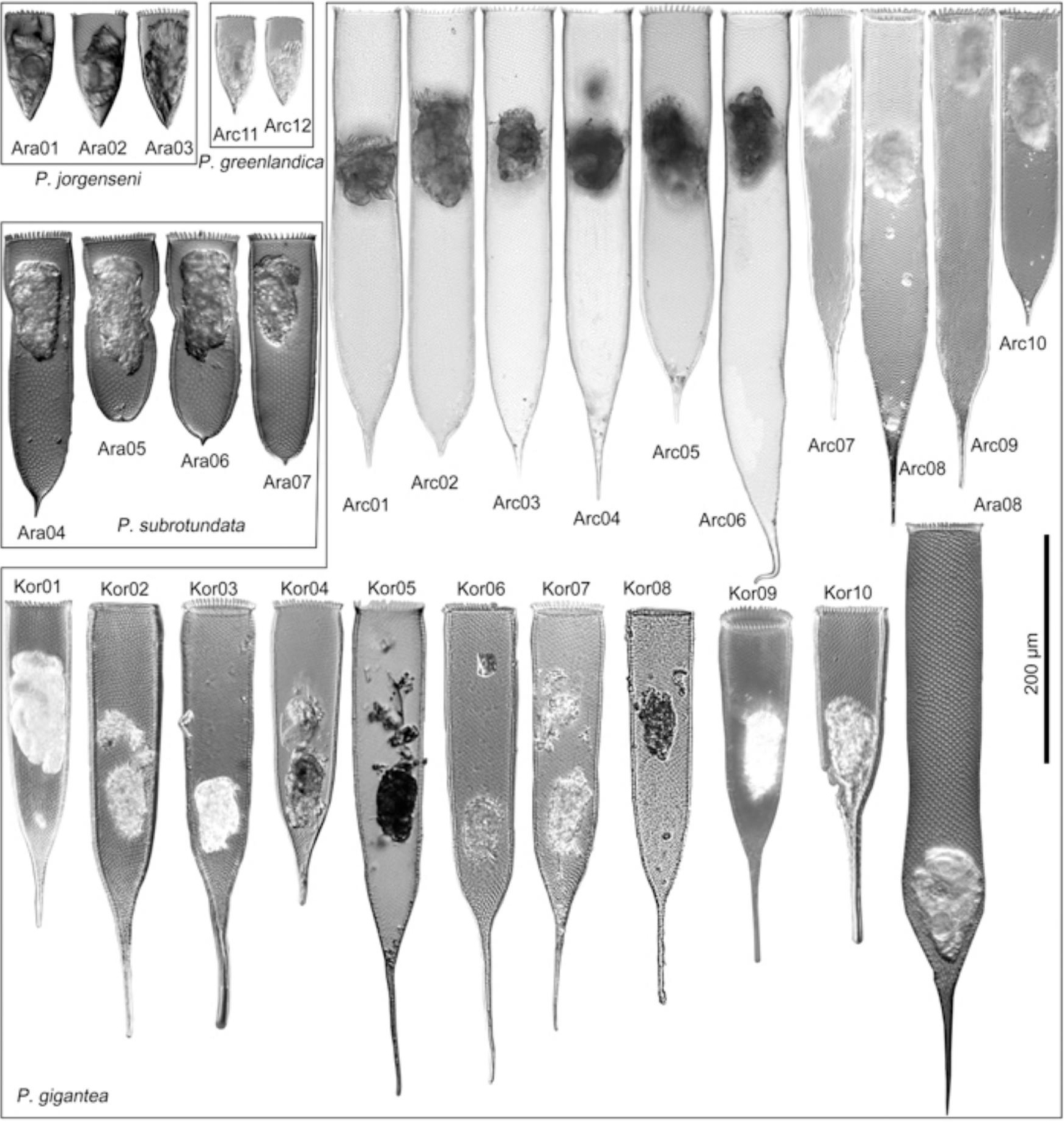


A

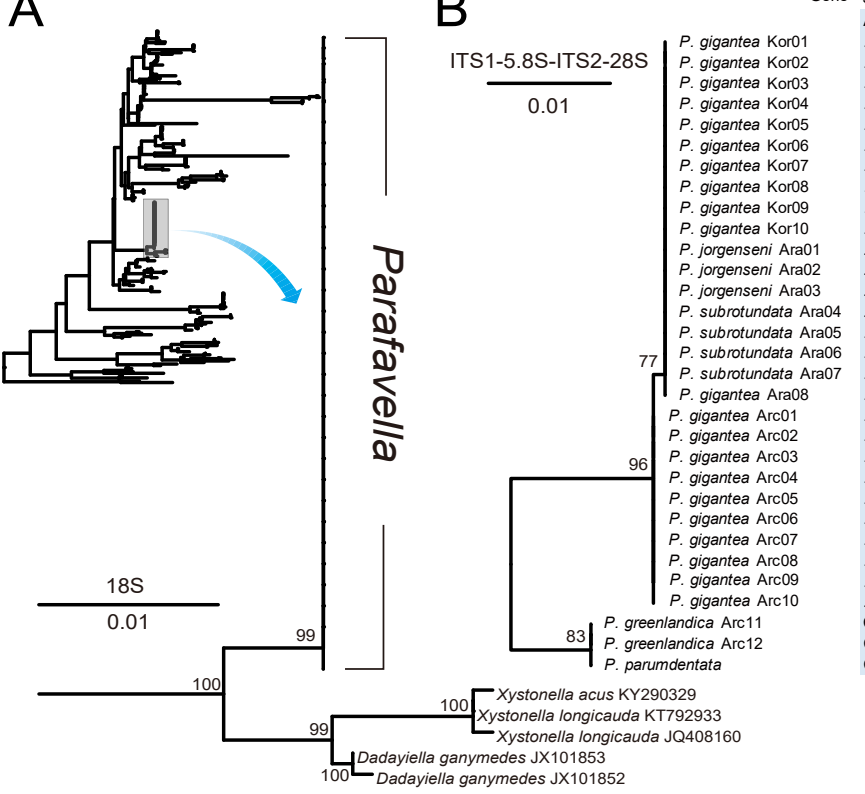

CTTCATCGCCGGTGTACCT MG594903

D

10 hdiv.

1 indiv

O Greenland Sea

O Bering Sea

- East/Japan Sea

ParO

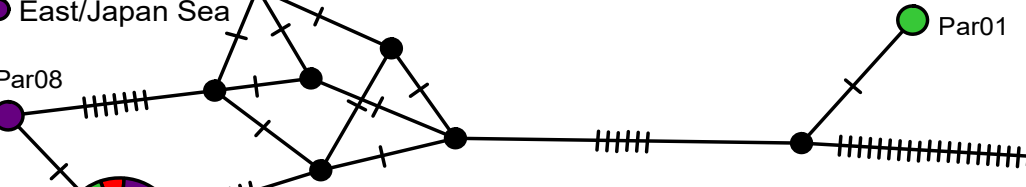

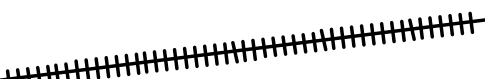

Par06

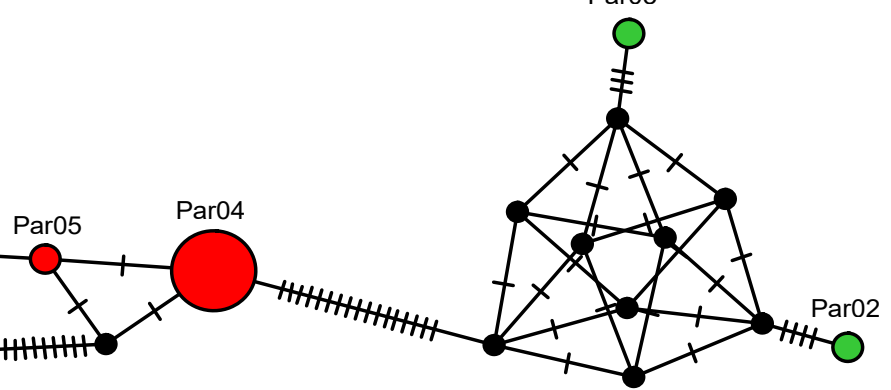




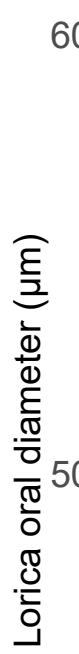

$60^{-}$

40

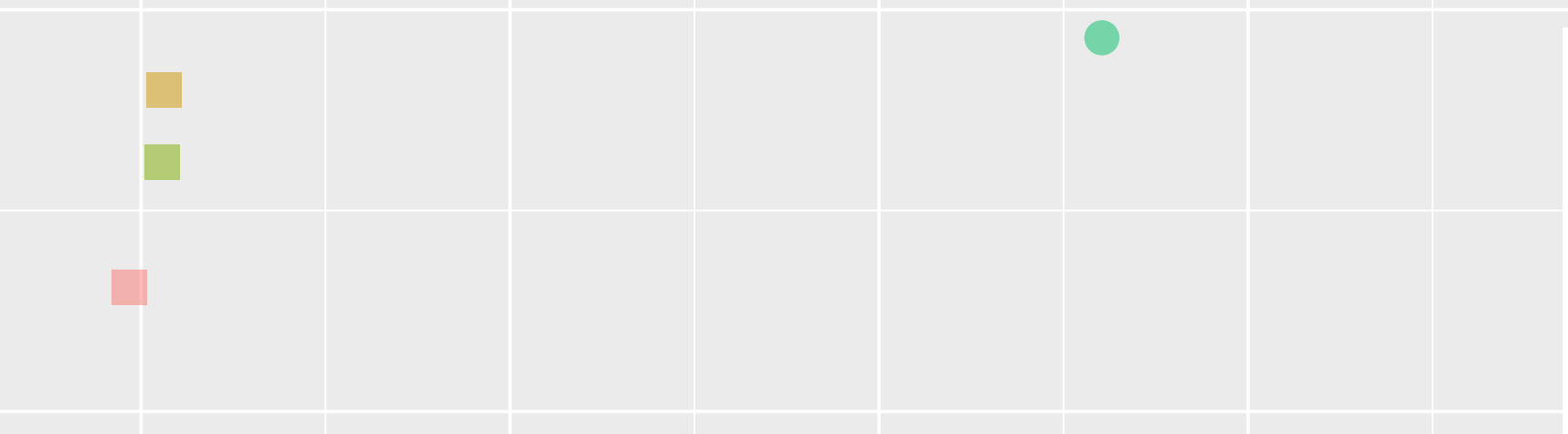

Haplotype

Par01

Par02

Par03

Par04

Par05

Par06

Par07

Par08

Species

P_gig

P_gre

$P$ jor

-P_sub

100

200

300

Length $(\mu \mathrm{m})$

500 